\title{
VITAMIN E AMELIORATES THE TOXIC EFFECT OF AMIODARONE ON THYROID GLAND IN RATS: A HISTOLOGICAL AND ULTRASTRUCTURAL STUDY
}

\author{
Original \\ Article \\ Rabab Ahmed Rasheed ${ }^{1}$, Sherif Fahmy Arsanyos ${ }^{2}$ \\ ${ }^{1}$ Lecturer of Histology; Department of Histology; Faculty of Medicine, October 6 University, \\ Egypt \\ ${ }^{2}$ Lecturer of Anatomy and Embryology, Department of Anatomy and Embryology, Faculty of \\ Medicine, Cairo University
}

\begin{abstract}
Background: Amiodarone is a highly effective and class III antiarrhythmic drug. It can be used to treat wide range of arrhythmias. However, it is markedly concentrated in tissues leading to multiple adverse effects mainly on thyroid gland. The concomitant use of vitamin E with amiodarone in treatment of arrhythmias can ameliorate the hazardous effects of amiodarone on thyroid gland

Aim of work: The aim of this work is to study the histological and ultrastructural effects of amiodarone as antiarrhythmic drug on the thyroid gland, as well as the ability of vitamin E to protect against amiodarone induced thyroid damage.

Material and methods: Thirty adult male albino rats (weighing 150-200 g), were used in the study. Rats were divided into three groups (10 per group): Group A (Control group); Group B (Amiodarone treated group) and Group C (Amiodarone + Vitamin E treated group). Rats were sacrificed after 6 weeks of amiodarone administration. Thyroid gland was examined histologically and ultrastructurally.

Results: Histological and ultrastructure examination of thyroid glands of rats treated with amiodarone showed disorganized follicles. Follicular epithelium showed focal disruption and desquamation. The interfollicular tissue showed increased collagen deposition. Electron microscopic examination revealed irregular nuclei, dilated rough endoplasmic reticulum and swollen mitochondria. Concomitant administration of vitamin E showed marked amelioration of hazardous effects of amiodarone with improved histologic and ultrastructural signs

Conclusion: Amiodarone induces damage of the thyroid gland. Administration of vitamin E protects the thyroid gland and attenuates histopathological changes induced by amiodarone.
\end{abstract}

Key Words: Amiodarone, Thyrotoxicity, Ultrastructure, Vitamin E.

Revised: 24 October 2018, Accepted: 17 December 2018

Corresponding Author: Rabab Ahmed Rasheed, Lecturer of Histology; Department of Histology; Faculty of Medicine, October 6 University, Egypt, Tel.: +201001022257, E-mail: rasheedrabab@gmail.com.

ISSN: 1110-0559, Vol. 2, No. 1

\section{INTRODUCTION:}

Amiodarone is the most commonly used antiarrhythmic drug. Although considered a class III antiarrhythmic drug, it has also class I, class II and class IV pathways ${ }^{[1]}$. It can be used to manage variable cases of arrhythmia like supraventricular and ventricular tachyarrhythmias. Amiodarone is a safe drug which is tolerated in patients with left ventricular systolic function, like torsades de pointes ${ }^{[2]}$. Amiodarone is a benzofuran compound that has $37 \%$ iodine by molecular weight so that it releases a 20 to 40 times higher iodine level compared to the daily required iodine of $150300-\mu \mathrm{g}^{[3]}$. However, its lipophilic property and its long half-life, increases the concentration of amiodarone in variable tissues leading to multiple hazardous effects as photosensitivity, corneal microdeposits, pulmonary toxicity, hepatotoxicity, peripheral neuropathy and thyroid dysfunction ${ }^{[4,5,6,7]}$. Recently, bilateral vestibulopathy was described as an adverse effect of amiodarone which is a debilitating disorder characterized by the decreased function of vestibular apparatus ${ }^{[8]}$.

Amiodarone can lead to either hypothyroidism or hyperthyroidism, depending on daily dietary allowance of iodine ${ }^{[4]}$. In liver, amiodarone deactivates type I 5 '-deiodinase (5'-D), which eliminates an atom of iodine from T4 to generate $\mathrm{T} 3$ and from rT3 to produce $3,3^{\prime}$-diiodothyronine (T2 ${ }^{[9]}$. In addition, due to the nearly similar structure of amiodarone and thyroid hormones, amiodarone can act at many cell types and organs including the liver and pituitary as a thyroid hormone challenger, decreasing the uptake of thyroid hormones by tissue cells. Both mechanisms result in the increased serum T4 and the decreased serum T3 concentration in euthyroid subjects given long-term amiodarone therapy ${ }^{[10,11]}$.

Ursella et al., 2006, reported that amiodarone had a cytotoxic effect on thyroid cells that is mainly due to either a direct effect of the drug on thyroid cells or 
due to the toxic action of excess iodine released from amiodarone ${ }^{[12]}$. N-Monodesethylamiodarone [DEA], the main amiodarone metabolite, is even more cytotoxic on thyroid cells than amiodarone ${ }^{[13]}$. Vereckei et al. (1993) suggested that the production of free radicals and lipid peroxidation played a role in amiodarone-induced toxicity ${ }^{[14]}$.

Apoptosis in thyroid cells is produced by the effect of excess iodine through a p53- mechanism with subsequent oxidative stress which leads to the production of reactive oxygen species with an increase in lipid peroxide levels ${ }^{[15]}$.

It was shown that amiodarone administration is associated with histological changes indicating thyroid cytotoxicity. These include thyroid tissue damage with hemorrhage and necrosis. Electron microscopic examination showed a remarkable cellular changes in the form of the dilated rough endoplasmic reticulum, inclusion lysosomes, dilated Golgi bodies, mitochondrial distension and nuclear degeneration ${ }^{[13]}$. These findings might be comparable with the disruption of protein sorting pathways leading to a drug-induced form of endoplasmic reticulum storage disease ${ }^{[16]}$. The fact that amiodarone, being amphiphilic, strongly binds to intralysosomal phospholipids, making them indigestible by phospholipases, may contribute to these subcellular changes ${ }^{[17]}$.

Reactive oxygen species are chemically reactive molecules that contain oxygen. Accumulation of these molecules may become injurious to cell structures and be involved as an underlying agent in various pathological conditions. During oxidative stress, the balance between oxidation and anti-oxidation becomes disrupted leading to hazardous events such as lipid peroxidation (LPO) and oxidative DNA damage ${ }^{[18]}$.

Dronedarone is another benzofuran derivative, similar to amiodarone but less effective. It has no iodine content with no adverse effects proving that iodine is the most toxic component of Amiodarone ${ }^{[19]}$.

Vitamin E has high affinity to phospholipids, cholesterol and triglycerides (the three main structural elements of the cell membrane, mitochondria and endoplasmic reticulum) thus vitamin $\mathrm{E}$ appears to be the first line of defense against peroxidation of the polyunsaturated fatty acids of the cell membrane ${ }^{[20]}$. It can break free radical chain reactions due to its ability to transfer phenolic hydrogen to peroxyl free radical of the cell membrane producing a stable non-radical product finally excreted in bile. It augments and synergizes other antioxidant nutrients including $\beta$-carotenes, vitamin $\mathrm{C}$ and selenium to get rid of free radicals and peroxides ${ }^{[21]}$. It plays a leading role in controlling excess oxidative radical formed at cell membranes including mitochondrial membranes $^{[22]}$ inhibition of superoxide generation in neutrophils ${ }^{[23]}$ and decrease in collagenase expression in fibroblasts $^{[24]}$

\section{AIM OF STUDY:}

The aim of the present work was to investigate the effects of amiodarone on the thyroid gland of adult male albino rat and the possible protective role of vitamin E.

\section{MATERIALS AND METHODS:}

\section{Chemicals:}

1. Amiodarone: was supplied by Global Napi Pharmaceutical Co., Egypt (under license of Sanofi Aventis, France) in the form of tablets. Each tablet contains $200 \mathrm{mg}$ of amiodarone hydrochloride.

2. Vitamin E: was supplied by El Kahira Pharmaceutical Co., Egypt in the form of capsules. Each capsule contained $400 \mathrm{mg}$ of vitamin E.

\section{Animals:}

The present study was carried out on 30 adult male albino rats (Sprague-Dawley), weighing 150 - 200 g. The rats were obtained from the Animal house, Faculty of Medicine, Cairo University. The animals were acclimatized in the laboratory for a period of two weeks before carrying out the experiment. They were allowed free access to food and water ad libitum. They were housed in separate clean cages, five rats/cage under standard laboratory and environmental conditions approved by the Animal Ethics Committee, Cairo University. All procedures performed in the study were in accordance with the ethical standards of the institution of practice at which the studies were conducted.

\section{Experimental design:}

The animals were randomly divided into 3 groups (10 rats each) as follow:

1. Group A(Control group): received no medications and left to survive for 6 weeks.

2. Group B (Amiodarone treated): The amiodarone tablet was dissolved in $10 \mathrm{ml}$ of distilled water. It was administered orally via gastric gavage in a daily dose of $30 \mathrm{mg} / \mathrm{kg}$ body weight for 6 consecutive weeks ${ }^{[25]}$.

3. Group C (Amiodarone and vitamin $\mathrm{E}$ treated): Received amiodarone in a daily dose of $30 \mathrm{mg} /$ $\mathrm{kg}$ body weight orally via gastric gavage with simultaneous administration of vitamin E [100 $\mathrm{mg} / \mathrm{kg} /$ day ( $\alpha$-tocopherol acetate) dissolved in 2 $\mathrm{ml}$ vegetable oil] by oral gavages given 2 hours preceding amiodarone for 6 consecutive weeks ${ }^{[26]}$.

\section{Histological and ultrastructural assessment of rats'} thyroid gland:

After the end of the experimental period, all rats were anesthetized with ether and sacrificed by cervical dislocation. The thyroids of each animal were removed then divided into two parts. 
The first part was fixed in $10 \%$ formalin solution and embedded in paraffin wax. Sections of $5 \mu \mathrm{m}$ thickness were cut on a microtome and stained with haematoxylin and eosin (H \& E) for general histologic examination and Masson's trichrome stain to detect the density of collagen fibers deposition in the thyroid tissue ${ }^{[27]}$.

The second part was divided into $1 \mathrm{~mm}$ slices and was processed for transmission electron microscopy. Small blocks of tissue were fixed in $2.5 \%$ glutaraldehyde in $0.1 \mathrm{M}$ sodium cacodylate buffer at $4{ }^{\circ} \mathrm{C}$ for $6 \mathrm{~h}$, dehydrated in ascending grades of ethyl alcohol, embedded in EM bed 812 resin (EM bed 812 kit, Electron Microscopy Sciences, Hatfield, PA, USA) and polymerized at $60^{\circ} \mathrm{C}$ for 24 hours. To allow selection of the appropriate tissue area before proceeding to TEM, semi-thin sections were prepared at approximately $0.51-\mu \mathrm{m}$ thickness using glass knives and Leica Ultracut UCT ultra microtome and stained with $1 \%$ toluidine blue in $1 \%$ borax. Ultrathin sections $(7590-\mathrm{nm}$ thick) collected on 300 Ultrathin sections (7590- nm thick) collected on 300 mesh copper grids were contrast stained with uranyl acetate and lead citrate. These sections were examined in a JEOL transmission electron microscope (JEM-1400, JEOL, Tokyo, Japan) at $80 \mathrm{kV}$. Images were captured by a side-mounted CCD digital camera (AMT Optronics, $1632 \times 1632$ pixel format). The transmission electron microscopy was done in FARP TEM lab, Faculty of Agriculture, Cairo University-Research Park (CURP) ${ }^{[28]}$.

\section{Morphometric study:}

The area percentage of collagen fibers with Masson's trichrome stain was measured in 5 randomly different microscopic fields for each specimen at a magnification power of (x200). The morphomertrical studies were made using Leica Qwin 500 Image Analyzer computer system (Leica Microsystem Imaging Solution Ltd., Cambridge, UK) Faculty of Dentistry, Cairo University.

\section{Statistical analysis:}

The data obtained were analysed using SPSS software version 13 (SPSS Inc., Chicago, IL, USA), then compared by one-way analysis of variance (ANOVA) test followed by Tukey's test to compare different groups with the control group. The results were expressed as mean \pm standard deviation (SD). The differences were considered statistically significant if probability value $\mathrm{P}<0.05$ and highly significant if $\mathrm{P}<0.001$ and non-significant if $\mathrm{P}>$ $0.05^{[29]}$

\section{RESULTS:}

\section{Group A (Control group)}

\section{Hematoxylin and Eosin staining:}

Examination of hematoxylin and eosin stained sections of the thyroid gland of control rats revealed that it was formed of multiple variable sized follicles. Each follicle was lined by a single layer of cuboidal epithelial cells with centrally placed round nuclei. Follicular Lumina were filled with homogenous eosinophilic colloid (Fig.1)

\section{Masson's trichrome staining:}

Examination of Masson's trichrome stained sections of the thyroid gland of control rats showed thyroid follicles lined with cuboidal epithelium with rounded nuclei, filled with colloid. Fine collagen fibers were demonstrated as interfollicular blue strands (Fig. 2)

\section{Ultrastructural findings:}

Examination of ultrathin sections of the thyroid gland of control rats showed thyroid follicle lined with cubical follicular epithelium situated on thin basal lamina. The nuclei were euchromatic with peripheral chromatin surrounded by rough endoplasmic reticulum. The cytoplasm showed well developed Golgi apparatus, many lysosomes, colloid vesicles and many secretory vesicles. The free surface showed microvilli protruding in follicular lumen. Junctional complexes were seen between adjacent follicular cells (Figs. 3 and 4).

\section{Group B (Amiodarone treated group)}

\section{Hematoxylin and Eosin staining:}

Examination of hematoxylin and eosin stained sections of thyroid gland of rats of group B [Amiodarone treated] showed loss of normal follicular architecture. The follicles were disorganized and variable sized. Some follicles were empty; others had scanty colloid. The follicular epithelial cells were ballooned and severely vacuolated. The epithelium showed focal disruption at certain points. Some follicles show desquamated epithelium forming clusters in the lumen. Some apoptotic nuclei were also observed. The interfollicular tissue showed markedly congested blood vessels and mononuclear cellular infiltrates (Figs. 5 - 7).

\section{Masson's trichrome staining:}

Examination of Masson's trichrome stained sections of the thyroid gland of rats of group B [Amiodarone treated] showed irregular thyroid follicles with thickened wavy collagen bundles in between. The lining epithelium was markedly vacuolated with areas of focal disruption (Fig. 8).

\section{Ultrastructural findings:}

Examination of ultrathin sections of the thyroid gland of rats of group B [Amiodarone treated] showed flattened follicular epithelium. The nuclei had many shapes ranging from irregular flattened nuclei to markedly shrunken ones. Other nuclei were bizarrely shaped with dispersed chromatin. The cytoplasm showed marked vacuolization with markedly dilated rough endoplasmic reticulum. The mitochondria were swollen with lost cristae. Many lysosomes and colloid vesicles were distributed within the cytoplasm. Some parts of cytoplasm were rarified. The apical border of cytoplasm in other parts was protruded in follicular lumen with intact cell membrane. The free surface showed partially lost microvilli; other parts showed long microvilli protruding in the follicular lumen. 
The lumen showed clusters of desquamated follicular cells. Junctional complexes between adjacent follicular cells were clearly seen. Thick collagen bundles appeared in some sections (Figs. 9 - 13).

\section{Group C (Amiodarone + Vitamin E treated group) Hematoxylin and Eosin staining:}

Examination of hematoxylin and eosin stained sections of the thyroid gland of rats of group C [Amiodarone + Vitamin E] showed obvious structural improvement with variable sized thyroid follicles lined with vacuolated follicular epithelium. The interfollicular tissue showed mononuclear cellular infiltrates and mild vascular congestion (Fig. 14).

\section{Masson's trichrome staining:}

Examination of Masson's trichrome stained sections of the thyroid gland of rats of group C [Amiodarone + Vitamin E] showed variable sized thyroid follicles lined with vacuolated epithelium with thin collagen bundles in between (Fig. 15)

\section{Ultrastructural findings:}

Examination of ultrathin section of thyroid gland of rats of group C [Amiodarone + Vitamin E] showed follicular epithelium with irregular nuclei and prominent nucleoli. Some nuclei were indented, euchromatic with peripherally located chromatin. The cytoplasm showed mildly dilated basal rough endoplasmic reticulum, many lysosomes, colloid and secretory vesicles. Intact microvilli were protruded in the follicular lumen (Figs. 16 - 18).

\section{Morphometric results and statistical analysis:}

Quantitative morphometric measurements of the Masson's trichrome stained sections revealed that the mean area percent of collagen content in group B showed a statistically significant increase $(\mathrm{P}<0.05)$ when compared to that of the control group. Also, the mean area percent of collagen content in group $\mathrm{C}$ showed a statistically significant decrease $(\mathrm{P}=$ $0.001^{*}$ ) when compared to that of group B [Table 1]

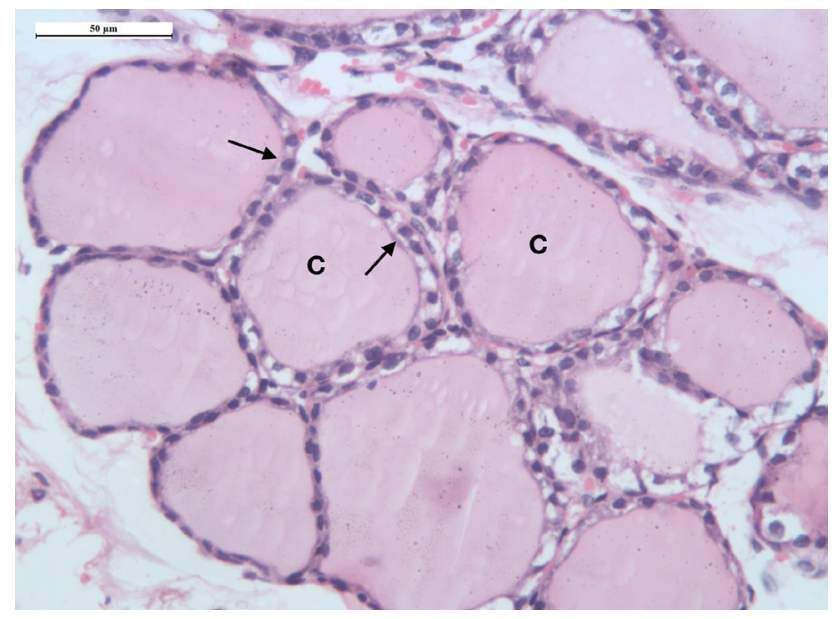

Fig. 1: A photomicrograph of thyroid gland of a control rat showing thyroid follicles lined with cuboidal epithelium with round central nuclei [arrows]. The lumen is filled with homogenous eosinophilic colloid [C] [H\&E X 200]

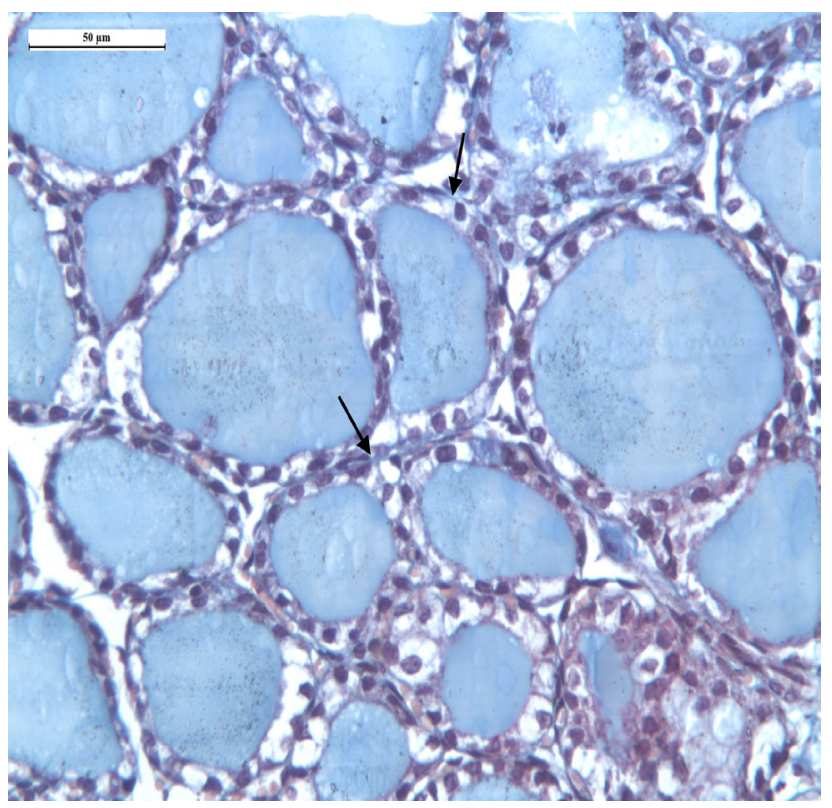

Fig. 2: A photomicrograph of thyroid gland of a control rat showing thyroid follicles lined with cuboidal epithelium with rounded nuclei, filled with colloid. Fine collagen fibers are seen between follicles [arrows] [Masson's trichrome X 200]

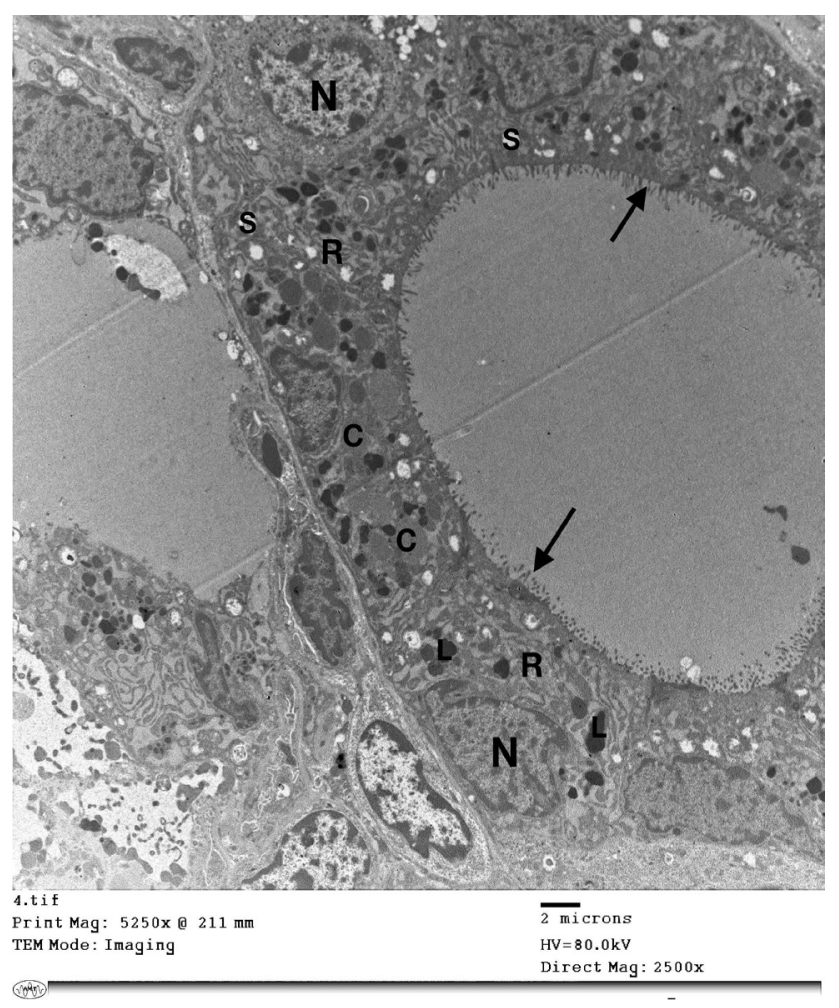

Fig. 3: An electron micrograph of ultrathin section of thyroid gland of a control rat showing thyroid follicle lined with cubical follicular epithelium situated on thin basal lamina. Nuclei are euchromatic with peripheral chromatin $[\mathrm{N}]$ surrounded by rough endoplasmic reticulum [R]. The cytoplasm shows lysosomes [L], colloid droplets [C] many secretory vesicles $[\mathrm{S}]$. The free surface shows microvilli protruding in follicular lumen [arrows] [X 2500] 


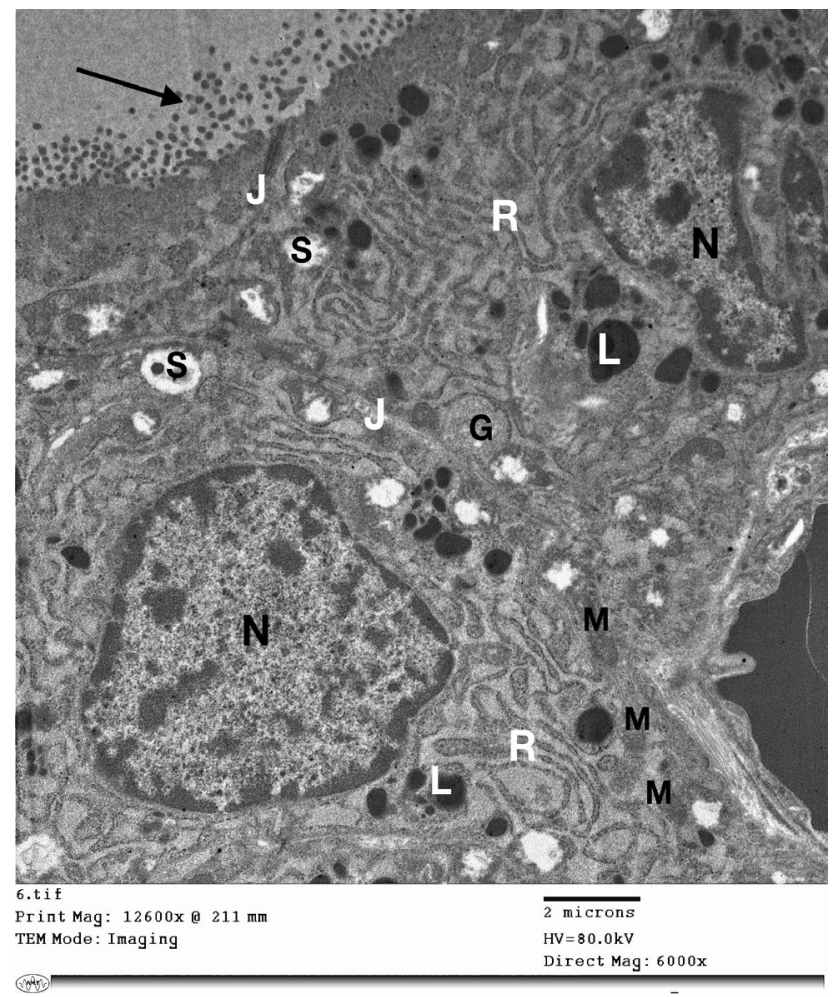

Fig. 4: An electron micrograph of ultrathin section of thyroid follicular cells of a control rat showing euchromatic nucleus with peripheral chromatin $[\mathrm{N}]$. The cytoplasm shows prominent rough endoplasmic reticulum [R], well developed Golgi apparatus [G], many lysosomes $[\mathrm{L}]$, mitochondria $[\mathrm{M}]$ and secretory vesicles $[\mathrm{S}]$. The apical surface shows microvilli [arrow]. Junctional complexes are seen between adjacent follicular cells [J] [X 6000]

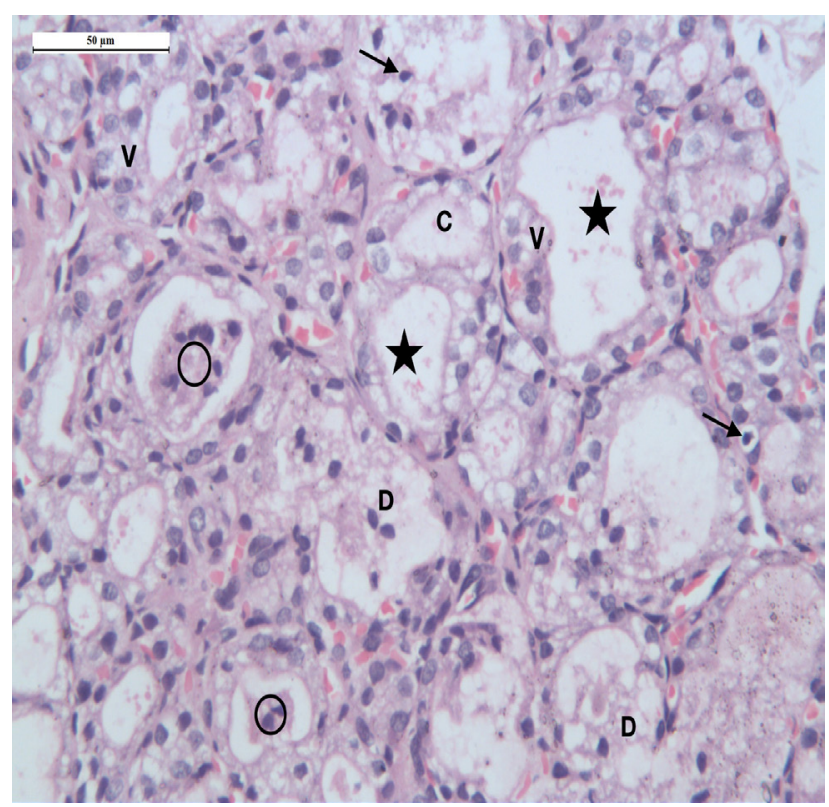

Fig. 5: A photomicrograph of thyroid gland of a rat of group B [amiodarone] showing disorganized small thyroid follicles. Some follicles are empty [stars]; others have scanty colloid [C]. The follicular epithelial cells are severely vacuolated [V]. The epithelium shows focal disruption [D]. Some follicles show desquamated epithelium forming clusters in the lumen [circles]. Some apoptotic nuclei are observed [arrows] [H\&E X 200]

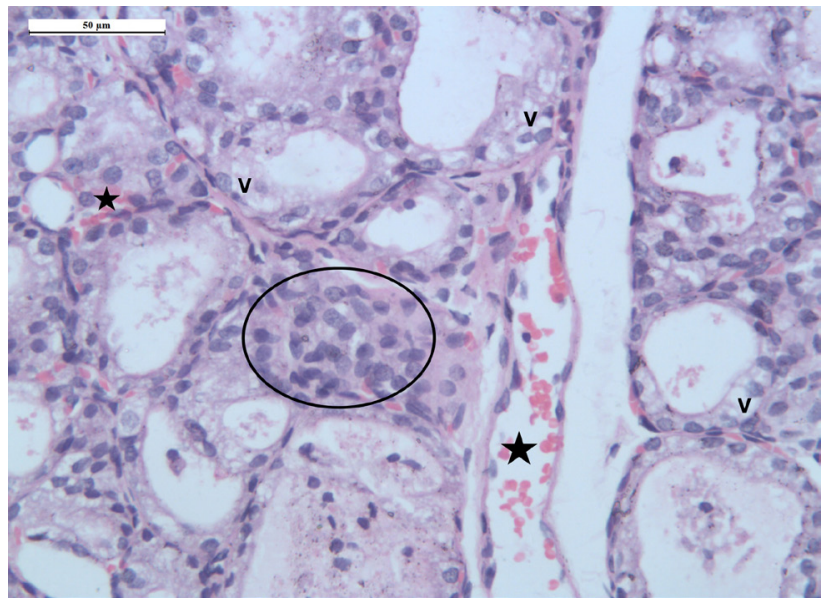

Fig. 6: A photomicrograph of thyroid gland of a rat of group B [amiodarone] showed disorganized thyroid follicles lined with vacuolated epithelium [V]. Blood vessels shows marked congestion [stars]. Interfollicular tissue shows mononuclear cellular infiltrates [circle]. [H\&E X 200]

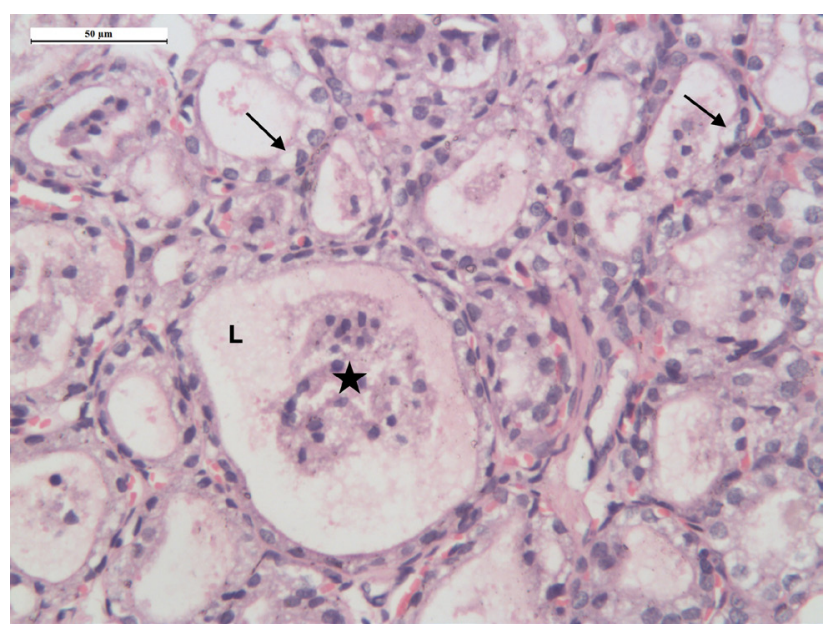

Fig. 7: A photomicrograph of thyroid gland of a rat of group B [amiodarone] showed large thyroid follicle $[\mathrm{L}]$ surrounded by smaller ones. The large follicle shows cluster of desquamated epithelium in the lumen [star]. Ballooned follicular cells can be clearly seen [arrows]. [H\&E X 200]

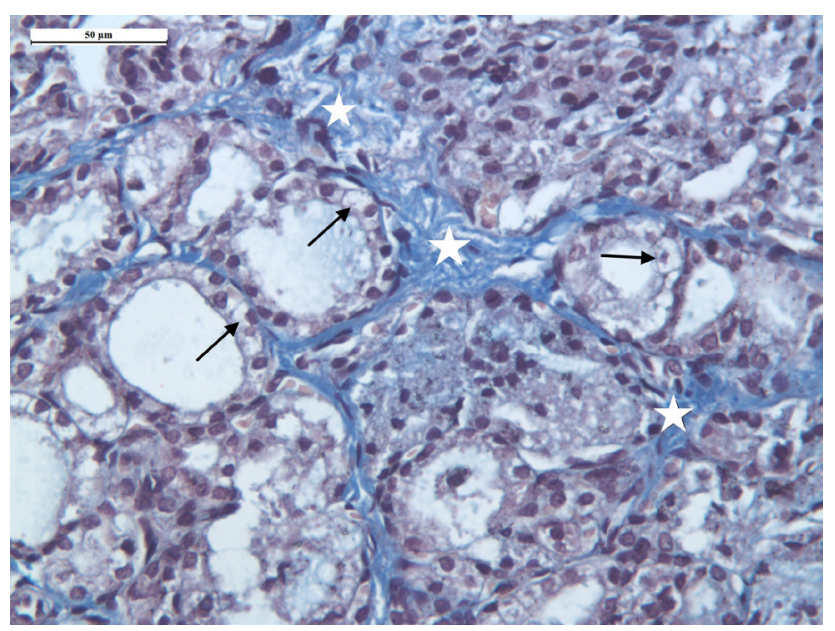

Fig 8: A photomicrograph of thyroid gland of a rat of group B [amiodarone] showing irregular thyroid follicles with thickened wavy collagen bundles in between [stars]. The lining epithelium is markedly vacuolated [arrows]. [Masson's trichrome X 200] 


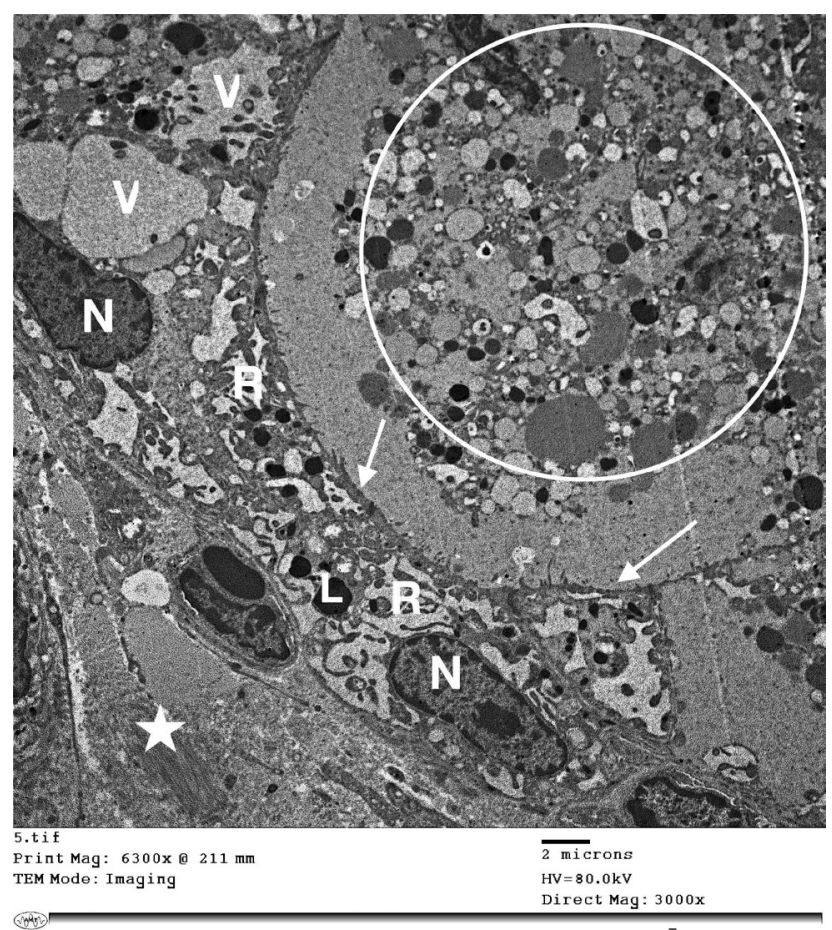

Fig. 9: An electron micrograph of ultrathin section of thyroid gland of a rat of group B showing a thyroid follicle lined with flattened follicular cells with irregular flat nuclei [N]. The cytoplasm shows marked vacuolization [V] with dilated rough endoplasmic reticulum [R] and many lysosomes [L]. The free surface shows partially lost microvilli [arrows]. The lumen shows clusters of desquamated follicular cells [circle]. Thick collagen bundles can be seen [star] [X 3000]

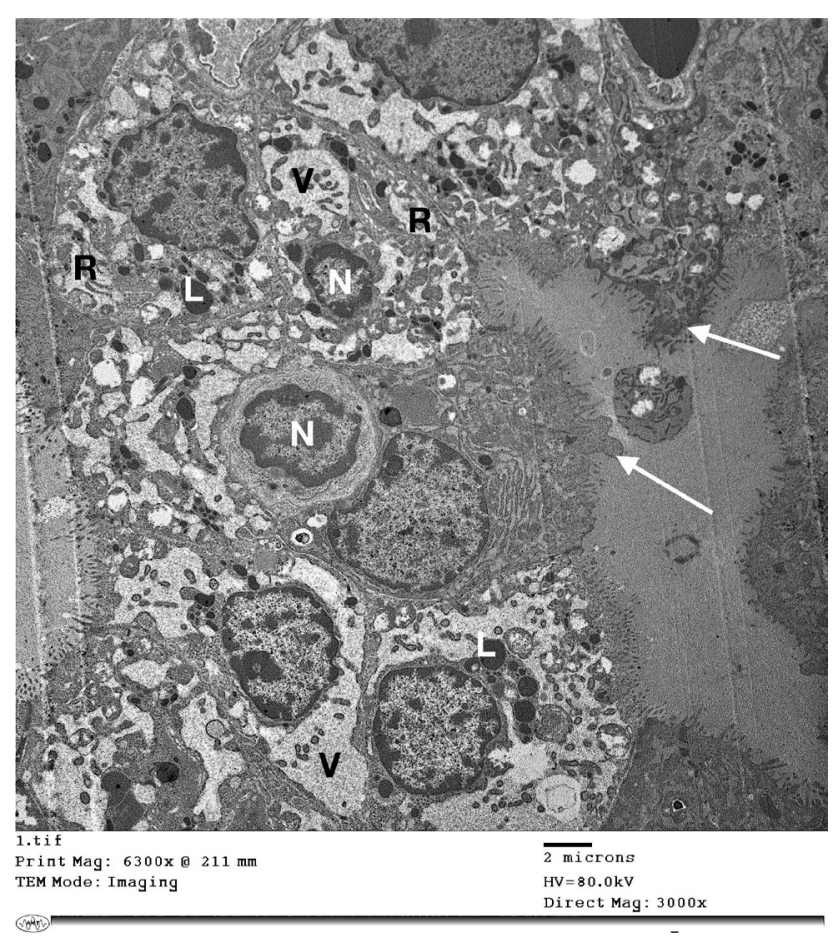

Fig. 10: An electron micrograph of ultrathin section of thyroid gland of a rat of group B showing follicular epithelium with some shrunken nuclei [N]. Cytoplasm shows marked vacuolization [V] and markedly dilated rough endoplasmic reticulum [R]. Many lysosomes [L] are distributed within the cytoplasm. The apical border of cytoplasm is protruded in follicular lumen [arrows] with intact cell membrane. [X 3000]

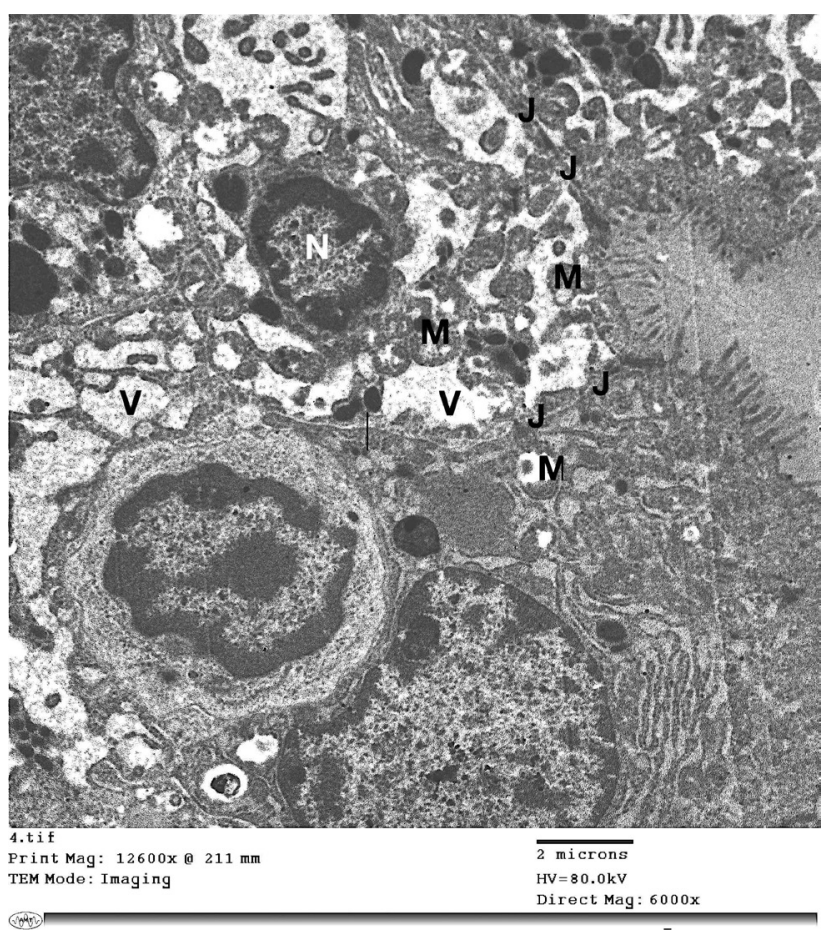

Fig. 11: A higher magnification of the previous electron micrograph of ultrathin section of thyroid gland of a rat of group B showing markedly shrunken nucleus [N]. The cytoplasm is markedly vacuolated [V]. The mitochondria are swollen with lost cristae [M]. Junctional complexes between adjacent follicular cells are seen [J] [X 6000]

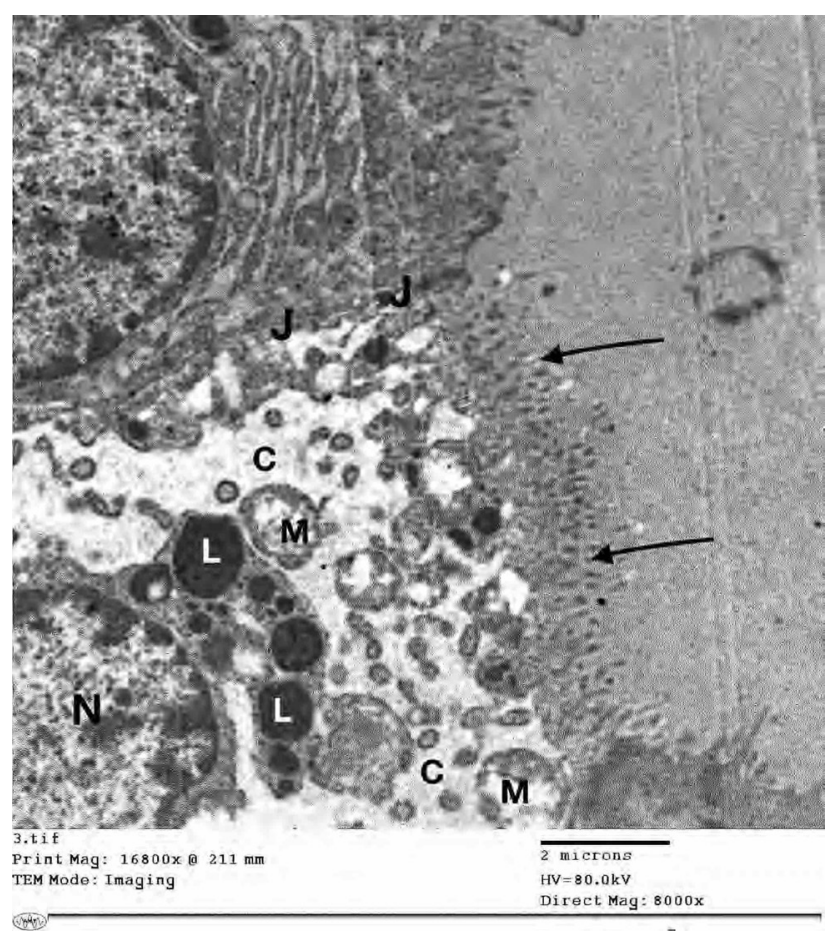

Fig. 12: An electron micrograph of ultrathin section of thyroid gland of a rat of group B showing rarified cytoplasm [C], swollen mitochondria with lost cristae [M] and some lysosomes [L]. The nucleus shows dispersed chromatin [N]. The apical surface shows intact microvilli protruding in lumen [arrows]. Junctional complexes can be clearly seen between adjacent follicular cells [J] [X 8000] 


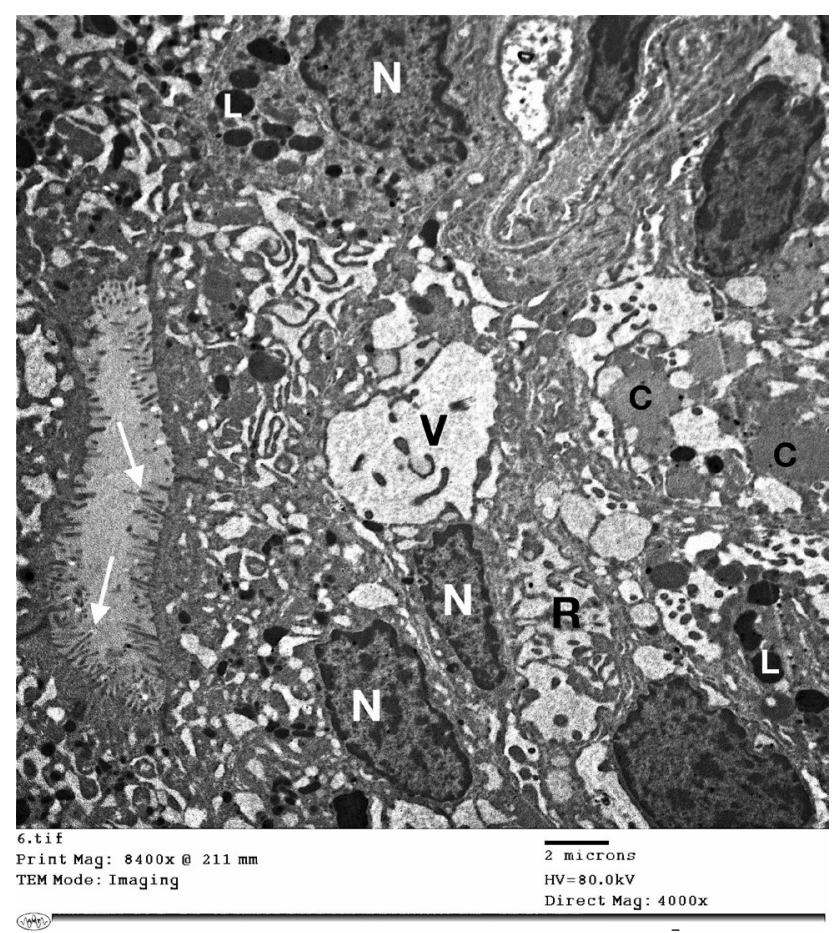

Fig. 13: An electron micrograph of ultrathin section of thyroid gland of a rat of group B showing bizarre nuclei with dispersed chromatin [N]. The cytoplasm shows vacuolization [V] with marked dilatation of rough endoplasmic reticulum [R], some lysosomes [L] and colloid droplets [C]. Long microvilli are seen protruding in lumen [arrows]. [X 4000]

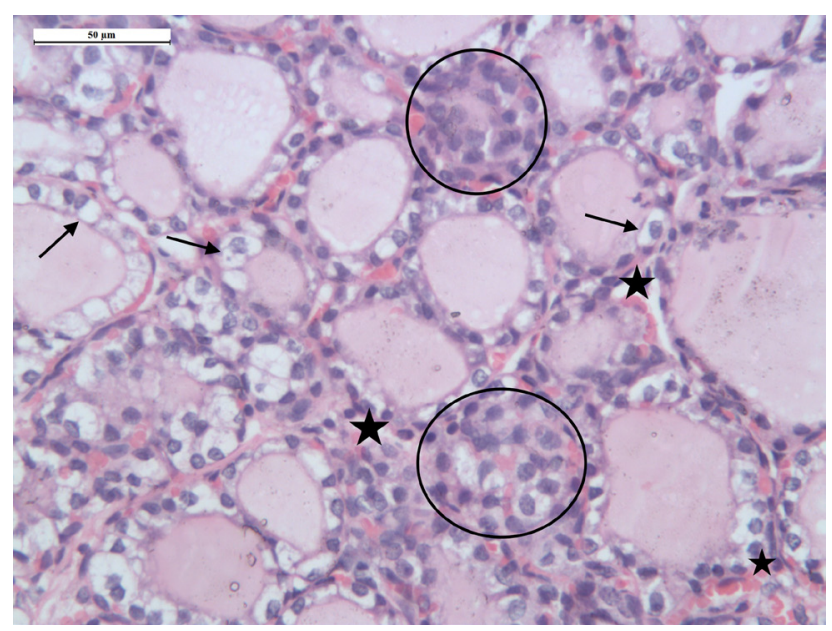

Fig. 14: A photomicrograph of thyroid gland of a rat of group $C$ showing variable sized thyroid follicles lined with vacuolated follicular epithelium [arrows]. Inter follicular mononuclear cellular infiltrates [circle] with mild vascular congestion [stars] [H\&E X 200]

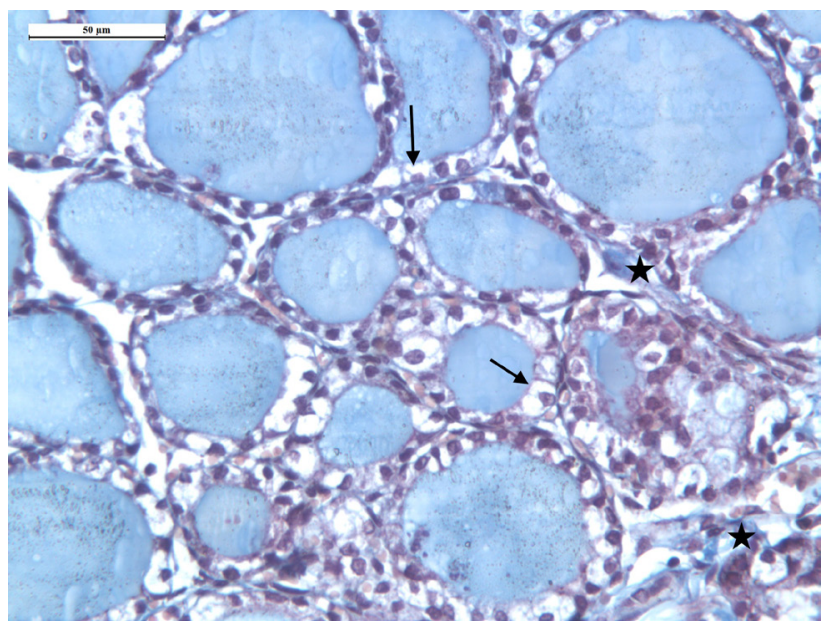

Fig 15: A photomicrograph of thyroid gland of a rat of group $C$ showing variable sized thyroid follicles lined with vacuolated epithelium [arrows] with thin collagen bundles in between [stars].[Masson's trichrome X 200]

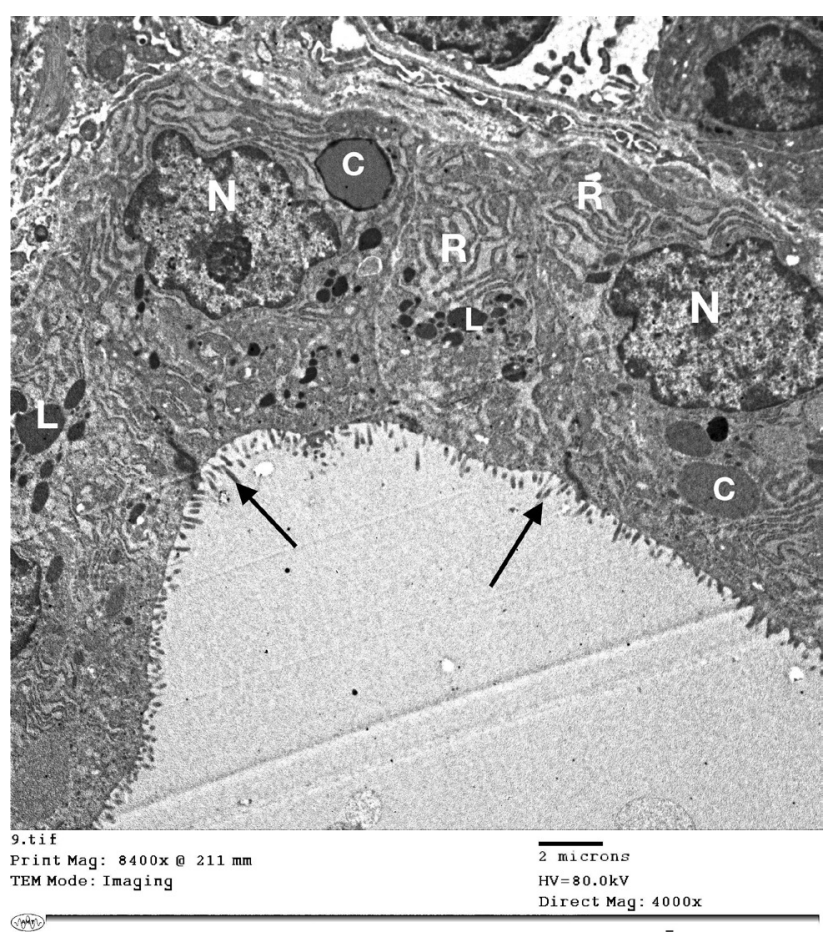

Fig. 16: An electron micrograph of ultrathin section of thyroid gland of a rat of group $\mathrm{C}$ showing follicular epithelium with irregular nucleus and prominent nucleolus $[\mathrm{N}]$. Cytoplasm shows mildly dilated basal rough endoplasmic reticulum [R], many lysosomes [L] and colloid droplets [C]. Intact microvilli are protruding in follicular lumen [arrows].

[X 4000] 


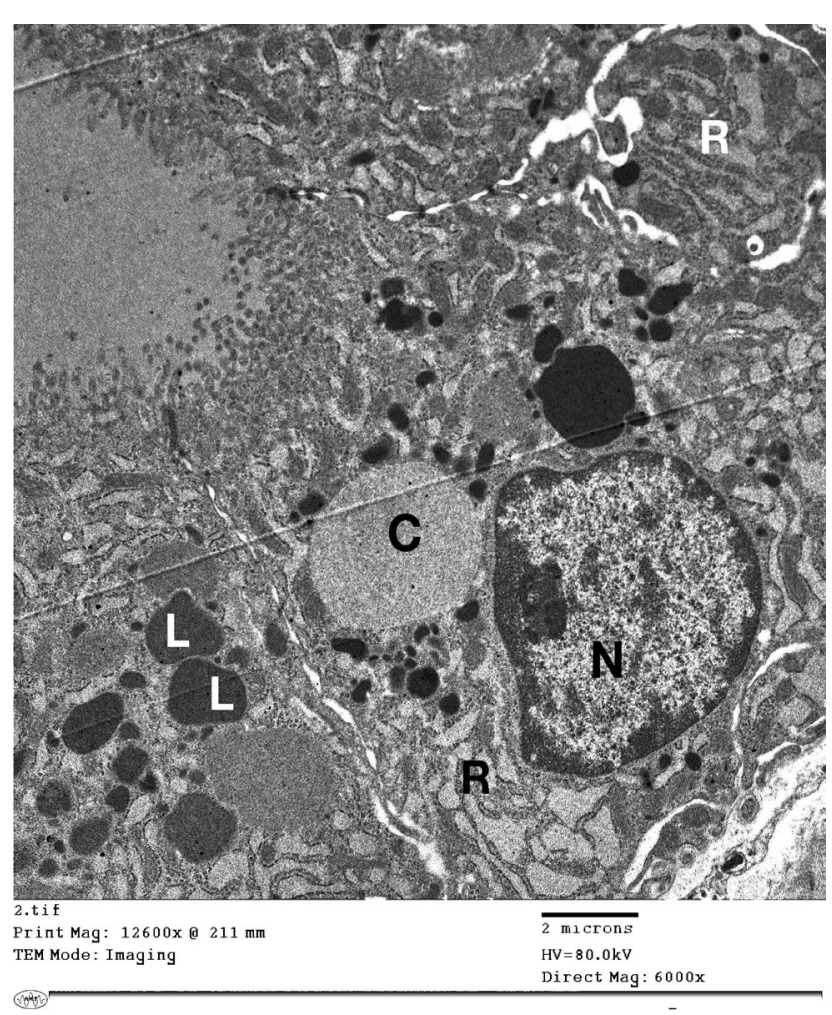

Fig. 17: An electron micrograph of ultrathin section of thyroid gland of a rat of group $\mathrm{C}$ showing follicular cells with euchromatic nucleus with peripherally located chromatin and prominent nucleolus $[\mathrm{N}]$. The cytoplasm shows large colloid droplets [C] and many lysosomes [L]. Mildly dilated rough endoplasmic reticulum can be noticed [R] [X 6000]

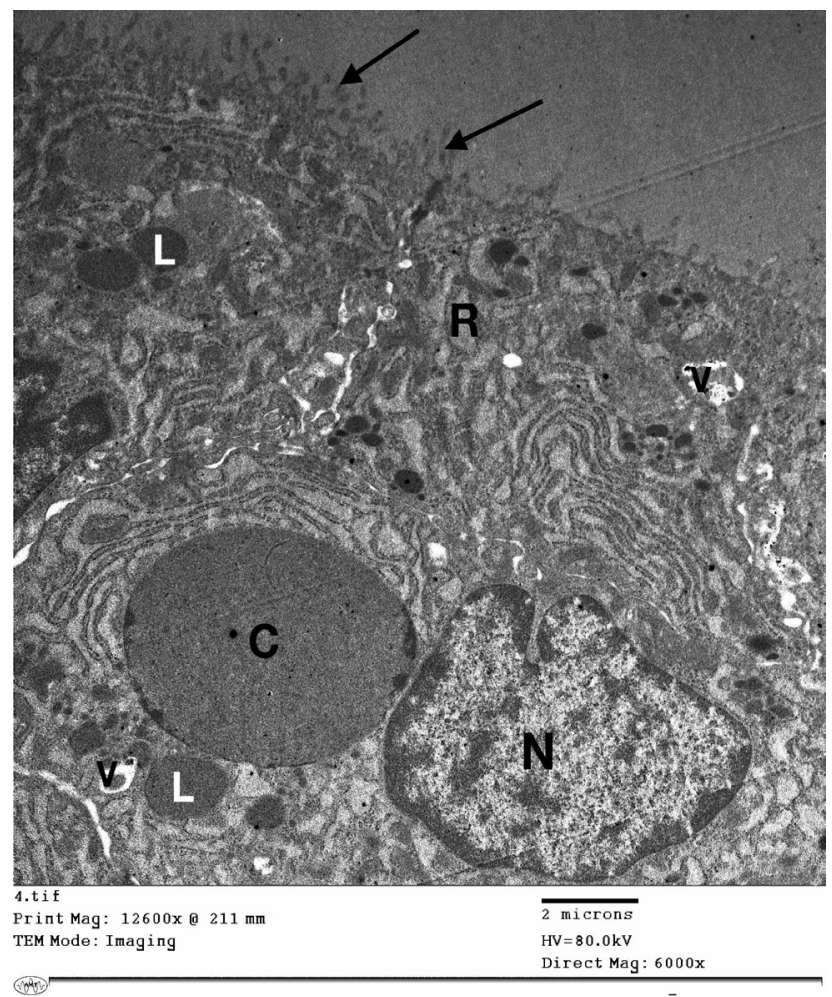

Fig. 18: An electron micrograph of ultrathin section of thyroid gland of a rat of group $\mathrm{C}$ showing indented nucleus with fine peripheral chromatin [N]. Cytoplasm shows mildly dilated rough endoplasmic reticulum [R], a huge colloid droplet [C], many lysosomes [L] and secretory vesicles [V]. The free surface shows intact microvilli protruding in follicular lumen [arrows] [X 6000]
Table1: showing the significant decrease in the amount of collagen in group C compared to group B

\begin{tabular}{ccccccc}
\hline & Group & Group & Group & & P-value & \\
& A & B & C & & & \\
\hline & & & & & & \\
Mean & 0.667 & 17.016 & 3.89 & 0.000 & $0.001 *$ & 0.000 \\
\pm & \pm & \pm & \pm & A Vs B & B Vs C & C Vs A \\
SD & 0.187 & 4.772 & 0.402 & & & \\
& & & & & & \\
*Significant & & & & & \\
\hline
\end{tabular}

SD: Standard Deviation, P-value $>0.05$ : non-significant, $\mathrm{P}$-value $<0.05$ : significant,

P-value $<0.001$ : highly significant

\section{DISCUSSION:}

Although Amiodarone has been proved to be highly effective in controlling cardiac arrhythmias, its clinical use is mainly limited due to its hazardous effect especially on the thyroid gland which in particular was investigated in the present study. The possible protective effect of vitamin $\mathrm{E}$ was also investigated in this study as it is one of the antioxidants ${ }^{[22]}$.

The oral intake of amiodarone was chosen in this study because it is similar to the conventional clinical situation. This runs in line with Mehta et al. (2008) who stated that this mode of administration approximates the human case $^{[30]}$. The dose regimen of amiodarone used in the present study was $30 \mathrm{mg} / \mathrm{kg} /$ day for six weeks ${ }^{[25]}$. Concomitant supplementation of vitamin E ( $\alpha$-tocopherol acetate) was given in a daily dose of $100 \mathrm{mg} / \mathrm{kg}$ dissolved in $2 \mathrm{ml}$ of vegetable oil, for six weeks with amiodarone ${ }^{[26]}$.

In the present study, in Amiodarone treated rats, focal disruption of some thyroid follicular cells, also follicles containing exfoliated cells in their lumina were noticed. The follicular epithelium showed markedly vacuolated epithelium. Detached microvilli in the lumen of some follicles were noticed. El-Sayed et al., (2007) found that therapeutic dose of amiodarone leads to irregular shape and size of thyroid acini with small cystic follicles that contain a scanty amount of colloid. The lining is columnar epithelium with a scanty amount of cytoplasm and vesicular nuclei. On the other hand, under a toxic dose of amiodarone, marked epithelial hyperplasia of the thyroid follicles was seen as they were lined with stratified columnar epithelium. Some follicles showed closed lumen with the absence of colloid content. Fibrous tissue was increased between the thyroid follicles ${ }^{[13]}$.

Nakazawa et al., (2008) reported that thyroid follicles become markedly enlarged and filled with colloid substance, and lined with flattened follicular cells. Many follicular cells contained vacuoles and yellowish pigment in the cytoplasm. Few inflammatory cells and small collections of fibrosis were present among the follicles ${ }^{[31]}$. These changes could be attributed to the direct toxic effect of amiodarone and its metabolites ${ }^{[15]}$. 
Concerning nuclear changes after amiodarone administration, many follicular cells revealed pyknotic nuclei which indicate cell degeneration. This was in agreement with Mehta et al. (2008) who noted pyknotic nuclei in the epithelium of many thyroid follicles of an amiodarone-induced thyrotoxicosis patient ${ }^{[30]}$. Iodine component of amiodarone is blamed to be the leading cause of this nuclear change through a p53- mechanism with subsequent oxidative stress ${ }^{[15]}$.

Concerning changes in the interfollicular connective tissue content, a significant increase in collagen fibers content [P-value $<0.05]$, congested blood vessels and lymphocytic infiltration were observed in the thyroid gland following amiodarone intake. Similar finding in human cases was described by El Sayed et al. (2007) who reported that amiodarone-induced degenerative and destructive follicular lesions, hemorrhage with focal fibrosis ${ }^{[13]}$. This could be attributed to inflammatory reaction secondary to direct toxic effects of amiodarone and its metabolites. Pitsiavas et al. (1997) stated that lymphocytic infiltration occurred secondary to autoimmune thyroiditis secondary to amiodarone therapy ${ }^{[16]}$.

Ultrastructural results of the present study confirmed the previously mentioned nuclear changes. Some nuclei appeared irregular with chromatin condensation. This was in agreement with El-Sayed et al. (2007) who observed apoptotic changes in the thyrocytes of amiodarone treated rats $^{[13]}$. Similar changes were also comparable to Gross et al. (1989) who reported similar nuclear changes in rat hepatocytes exposed to amiodarone ${ }^{[32]}$. Muller et al. (2011) stated that amiodarone might induce apoptosis either directly or indirectly due to its high iodine content ${ }^{[33]}$.

In the present work, electron microscopic examination of the thyroid gland under amiodarone administration revealed marked dilatation of rough endoplasmic reticulum (rER) with loss of its normal lamellar arrangement. These observations were in accordance with El Sayed et al. (2007) ${ }^{[13]}$. Moreover, Gross et al. (1989) reported similar changes in the rough endoplasmic reticulum in hepatocytes treated with amiodarone ${ }^{[32]}$. Pitsiavas et al. (1997) declared that the dilatation of endoplasmic reticulum occurred due to the accumulation of iodinated thyroglobulin which resists proteolytic destruction. Also, this dilatation is an evidence of disruption to protein synthesis and sorting pathways with subsequent retention of protein inside the endoplasmic reticulum (endoplasmic reticulum storage disease) ${ }^{[16]}$.

In the present study, a high number of lysosomes was observed in the cytoplasm of thyrocytes. This finding goes along with Pitsiavas, et al., (1997) who confirmed the accumulation of secondary lysosomes in the thyroid of amiodarone treated rats ${ }^{[16]}$. This finding could be explained by the accumulation of highly iodinated thyroglobulin which was resistant to degradation by proteolytic enzymes as mentioned by Marino and McCluskey $(2000)^{[34]}$.
Regarding mitochondrial changes in amiodaronetreated rats (group B) the mitochondria were swollen. This was in agreement with El Sayed et al. (2007) who reported that mitochondria became distended with glycogen and explained this finding as a result of thyroid cell damage with hyperfunction ${ }^{[13]}$. Also, Spaniol et al. (2001) stated that amiodarone was a well-known mitochondrial toxin $^{[35]}$. Cappiello et al. (1995) suggested that amiodarone increases the permeability of the mitochondrial membrane with subsequent diffusion of glycogen synthesis enzymes that increase the intramitochondrial glycogen ${ }^{[36]}$. Also, Zaky and Eid, (2018) clarified that intramitochondrial accumulation of lipid droplets occurred due to inhibition of mitochondrial beta-oxidation by amiodarone therapy ${ }^{[20]}$.

In the present study, vitamin $\mathrm{E}$ was administered as a member of antioxidants. When vitamin $\mathrm{E}$ was administered in a dose of $100 \mathrm{mg} / \mathrm{kg} /$ day, dissolved in $2 \mathrm{ml}$ for six weeks together with amiodarone in group $\mathrm{C}$, the previously mentioned harmful effects on the thyroid gland caused by amiodarone exposure alone were decreased. These findings were in agreement with $\mathrm{Yu}$ et al., (2011) who found that vitamin E may increase thyroid antioxidant defenses and inhibit iodine-induced thyroid cytotoxicity ${ }^{[37]}$. Also, Zaki, and Eid, (2009) who observed that $\alpha$ tocopherol could protect rat hepatocytes in culture from the damaging effect of amiodarone ${ }^{[20]}$.

Murray et al. (2000) reported that vitamin E protects against peroxidation of polyunsaturated fatty acids, which were part of cellular and subcellular membrane phospholipids $^{[38]}$.

Sarma et al. (1997) stated that vitamin E is a potent antioxidant in biomembranes, particularly with respect to lipid peroxidation. They added that its penetration to a precise site in the membrane might be an important feature of the protection against highly reactive radicals ${ }^{[39]}$. Murray et al. (2000) mentioned also that, the phospholipids of mitochondria, endoplasmic reticulum and plasma membrane have high affinities for vitamin $\mathrm{E}$ and that the vitamin appeared to concentrate at these $\operatorname{sites}^{[38]}$.

Bedossa et al. (1994) mentioned that Vitamin E inhibited lipid peroxidation and caused a decrease in collagen gene expression in cultured human fibroblasts ${ }^{[40]}$. that was coping with the results of the present study that showed a significant decrease in the amount of collagen in group $\mathrm{C}[\mathrm{P}$-value $=0.001]$ when compared to group B. Agoston et al. (2003) added both antioxidant action and the protective role of vitamin $\mathrm{E}$ against amiodarone toxicity ${ }^{[26]}$.

\section{CONCLUSION:}

From the present work, it could be concluded that amiodarone therapy induces thyroid toxicity proved by histological and ultrastructural examination. Vitamin $\mathrm{E}$, as an antioxidant, ameliorates the adverse effects of amiodarone. 


\section{RECOMMENDATIONS:}

Routine evaluation of thyroid functions (Free T3, Free T4 \&TSH) before and during amiodarone therapy is highly recommended. Vitamin E supplementation is mandatory to minimize the adverse effects of amiodarone.

\section{REFERENCES:}

1. Singh, B.N.: Amiodarone as paradigm for developing new drugs for atrial fibrillation. J. Cardiovas. Pharmacol. 2008; 52 (4): 300 - 5.

2. Shenthar, J.; Rachaiah, J.M.; Pillai, V.; Chakali, S.S.; Balasubramanian, V. and Nanjappa, M.C.: Incidence of drug-induced torsades de pointes with intravenous amiodarone. Indian Heart Journal 2017; 69: 707 - 13.

3. Basaria, S. and Cooper, D.S.: Amiodarone and the thyroid. Am. J. Med. 2005; 118 (7): 706 -14.

4. Narayana, S.K.; Woods, D.R. and Boos, C.J.: Management of Amiodarone-Related Thyroid Problems. Therapeutic Advances in Endocrinology and Metabolism 2011; 2(3):11526-

5. Zidan, R. A.: Effect of long-term administration of amiodarone on rat lung and the possible protective role of vitamin E: a histological and immunohistochemical study. The Egypt. J. of Histo. 2011; 34:117-28.

6. Joshi, K.M. and Gill, M.K.: Amiodarone: A potential risk factor for retinal phototoxicity. Am.J. of Ophthal. Case Rep. 2017; 5:119 - 23.

7. Lafuente-Lafuente, C.; Alvarez, J., Leenhardt, A.; Mouly, S., Extramiana, F., Caulin, C.; FunckBrentano, C. and Bergmann, J.: Amiodarone concentrations in plasma and fat tissue during chronic treatment and related toxicity. Br. J. Clin. Pharmacol. 2009; 67(5): 511-19

8. Gürkov, R.: Amiodarone: A newly discovered association with bilateral vestibulopathy. Front. Neurol. 2018; 9: 119.

9. Martino, E.; Bartalena, L.; Bogazzi, F. and Braverman, L.E.: The effects of amiodarone on the thyroid. Endocr. Rev. 2001; 22(2): 240 - 54.

10. Ahmed, S.; Van Gelder,I.C.; Wiesfeld,A.C.; Vanhuisen, D.J. and Links, T.P.: Determinants and outcome of amiodarone-associated thyroid dysfunction. Clin. Endocrinol. (Oxf) 2011; 75(3): 388 - 94

11. Bogun, L. V.: Amiodarone-induced thyroid dysfunction: Clinical case with literature review. Journal of V. N. Karazin 2016; 32:627-

12. Ursella, S.; Testa, A., Mazzone, M. and Silveri, N. G.: Amiodarone-induced thyroid dysfunction in clinical practice. Eur. Rev. Med. Pharmacol. Sci. 2006; 10 (5): 269 -78
13. El Sayed, O. A.; Gawish, S. E.; Aweida, G. H. and Auda E. A.: Histopathological and biochemical toxic effect of amiodarone on thyroid gland in albino rat. The Egyptian Journal of Hospital Medicine 2007; 29: 463-74.

14. Vereckei, A.; Blazovics, A.; Gyorgy, I.; Feher, E.;Toth, M.; Szenasi, G.; Zsinka, A.;Foldiak, G. and Feher, J.: The role of free radicals in the pathogenesis of amiodarone toxicity. J. Cardiovasc. Electrophysiol. 1993; 4(2): 161 - 77.

15. Vitale, M.; Di Matola, T.; D’Ascoli, F.; Salzano, S.; Bogazzi, F.; Fenzi, G.; Martino, E. and Rossi, G.: Iodide excess induces apoptosis in thyroid cells through a p53-independent mechanism involving oxidative stress. Endocrinol. 2000; 141(2):598-605.

16. Pitsiavas, V.; Smerdely, P.; Li, M. and Boyages, S. C.: Amiodarone induces a different pattern of ultrastructural change in the thyroid to iodine excess alone in both the $\mathrm{BB} / \mathrm{W}$ rat and the Wistar rat. Euro. J. of Endocrinol. 1997; 137(1): 89-98.

17. Wiersinga, W.M.: Towards an animal model of amiodarone-induced thyroid dysfunction. Eur. J. Endocrinol. 1997; 137(1):15-7.

18. Ramachandran, H.D.; Narasimhamurthy, K. and Raina, P.L.: Effect of oxidative stress on serum and antioxidant enzymes in liver and kidney of rats and their modulation through dietary factors. Indian J. Exp. Biol. 2002; 40(9):101015-.

19. Hohnloser, S.H.; Crijns, H.J.; van Eickels, M.; Gaudin, C.; Page, R.L.; Torp-Pedersen, C. and Connolly, S.J.: Effect of dronedarone on cardiovascular events in atrial fibrillation. $\mathrm{N}$. Engl. J. Med. 2009; 360(7):66878-

20. Zaki, M.S.A. and Eid, R.A.: Role of Vitamin-E on rat Vitamine-E on rat liver-amiodarone: An ultrastructural study. Saudi J. Gastroenterol. 2009; 15(2): 104 - 10.

21. Wang, X. and Quinn, P.J.: The location and function of vitamin $\mathrm{E}$ in membranes (review). Mol. Membr. Biol. 2000; 17(3):14356-.

22. Packer, L.; Weber, S.U. and Rimbach, G.: Molecular aspects of alpha-tocotrienol antioxidant action and cell signalling. J. Nutr. 2001; 131(2), 369S-73S.

23. Kanno, T.; Utsumi, T.; Takehara, Y.; Ide, A.; Akiyama, J.; Yoshioka, T., Horton, A.A. and Utsumi, K.: Inhibition of neutrophil-superoxide generation by alpha-tocopherol and coenzyme Q. Free Radic. Res. 1996; 24(4):2819-.

24. Ricciarelli, R.; Maroni, P.; Ozer, N.; Zingg, J.M. and Azzi, A.: Age-dependent increase of collagenase expression can be reduced by alphatocopherol via protein kinase $\mathrm{C}$ inhibition. Free Radic. Biol. Med. 1999; 27(737-729:(8- 
25. Kolettis, T.M.; Agelaki, M.G.; Baltogiannis, G.G.; Vlahos, A.P.; Mourouzis, I.; Fotopoulos, A. and Pantos, C.: Comparative effects of acute vs. chronic oral amiodarone treatment during acute myocardial infarction in rats. Europace 2007; 9(11):1099104-.

26. Agoston, M.; Orsi, F.; Feher, E.; Hagymasi, K.; Orosz, Z.; Blazovics, A.; Feher, J. and Vereckei, A.: Silymarin and vitamin E reduce amiodaroneinduced lysosomal phospholipidosis in rats. Toxicology 2003; 190(3): 231 - 41.

27. Bancroft, J.D. and Gamble, M.N.: Theory and Practice of Histological Techniques. 5th ed., Churchill-Livingstone, London, Edinburgh 2002; 175.

28. Hanker, J. and Giammara, B.: Microwaveaccelerated cytochemical stains for the image analysis and the electron microscopic examination of light microscopy diagnostic slides. Scanning 1993; 15:6780-

29. Davies, H.T. and Crombie, L.K.: what are confidence intervals and p-values?. 2nd edition. Hayward Group Ltd. 2009; 16-.

30. Mehta, A.N.; Vallera, R.D.; Tate, C.R.; Sager, R.A. and Welch, B.J.: Total thyroidectomy for medically refractory amiodarone-induced thyrotoxicosis. Proc. (Bayl. Univ. Med. Cent.) 2008; 21(4): 3825-

31. Nakazawa, T.; Murata, S.; Kondo, T.; Nakamura, N.; Yamane, T.; Iwasa, S. and

32. Gross, S.A.; Bandyopadhyay, S.; Klaunig, J.E. and Somani, P.: Amiodarone and desethylamiodarone toxicity in isolated hepatocytes in culture. Proc. Soc. Exp. Biol. Med. 1989; 190(2): 1639-.

33. Muller, K.; Krohn, K.; Eszlinger, M.; Ludgate, $\mathrm{M}$ and Fuhrer, D: Effect of iodine on early stage thyroid autonomy. Genomics 2011; 97(2): 94 -
100.

34. Marino, M. and McCluskey, R.T.: Role of thyroglobin, endocytic pathway in the control of thyroid hormone release. Am. J. Phsiol. Cell Physiol. 2000; 279: 1295 - 306.

35. Spaniol, M.; Bracher, R.; Ha, H.R.; Follath, F. and Krahenbuhl, S.: Toxicity of amiodarone and amiodarone analogues on isolated rat liver mitochondria. J. Hepatol. 2001; 35(5): 62836-.

36. Cappiello, E.; Boldorini, R.; Tosoni, A.; Piraneo, S.; Bernasconi, R. and Raggi, U.: Ultrstructural evidence of thyroid damagein amiodaroneinduced thyrotoxicosis. J. Endocrinol.Invest. $1995 ; 18: 862-8$.

37. Yu, J.; Shan, Z.; Chong, W.; Mao, J.; Geng, Y.; Zhang, C.; Xing, Q.; Wang, W.; Li, N.; Fan, C.; Wang, H.; Zhang, H. and Teng, W.: Vitamin $\mathrm{E}$ ameliorates iodine-induced cytotoxicity in thyroid. J. of Endocrinol. 2011; 209: 299-306.

38. Murray, K.; Granner, D.; Mayes, P. and Rodwell, W.: Harper's Biochemistry twenty-fifth edition. Middle East edition. Librairie du Libnan. Beirut, Lebanon. 2000; 647949-

39. Sarma, J.S.; Pei, H. and Venkataraman, K.: Role of Oxidative Stress in Amiodarone-induced Toxicity. J. Cardiovasc. Pharmacol. Ther. 1997; 2(1): 5360-.

40. Bedossa, P.; Houglum, K.; Trautwein, C.; Holstege, A. and Chojkien, M.: Stimulation of collagen alpha 1 (I) gene expression is associated with lipid peroxidationin hepatocellular injury: a link to tissue fibrosis? Hepatology 1994; 19(5): $1262-71$. 


\title{
فيتامين ه يقلل الاثر الضار لعقار الاميودارون علي الغدة الدرقية في الفئران: دراسة هستولوجية و تركيبية دقيقة الاميودة
}

\author{
رباب أحمد راشد' ـ شريف فهمي أرسانيوس' إندة

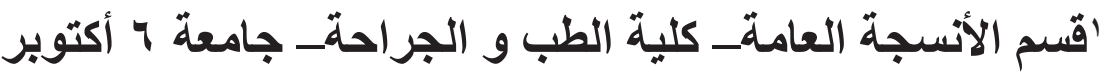 \\ r ققسم التشريح و الأجنة_ كلية الطب و الجراحة الطبة - جامعة القاهرة
}

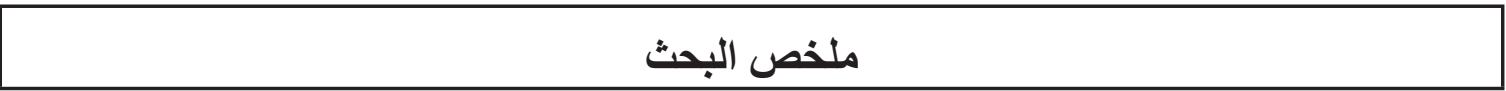

يعتبر الأميودارون عقار ا عالي الفعالية كمضاد لعدم إنتظام ضربات القلب. ولكنه يسبب تأثير ات ضارة في أنسجة الجسم نظر الإزدياد تركيزه بها بالذات في الغدة الدرقية. ومن الممكن أن يقوم فيتامين ه بتقليل هذا التأثثر.

إستهدف البحث دراسة التأثير ات الهستولوجية و التركيبية الاقيقة لعقار الأميودارون على الغدة الدرقية وأيضا الدور الوقائي المحتمل لفيتامين ه.

وقد أجريت هذه الدر اسة على ثلاثين من ذكور الفئران البيضاء (تراوح وزنها من 150 - 250 جرام) وتم تقسيم الفئران إلى ثلاث مجموعات (10 لكل مجموعة):

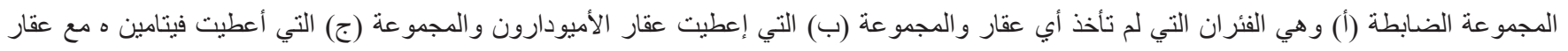
الأميودارون. وبعد 6 أسابيع من التجربة تم قتل الفئر ان وفحص الغدة الدرقية بالميكروسكوب الضونئي و الفئي الميكروسكوب الاليكتروني

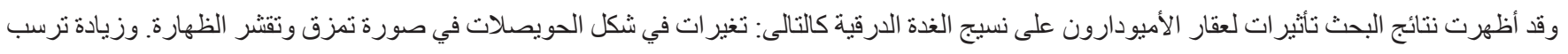

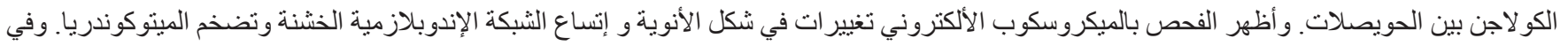

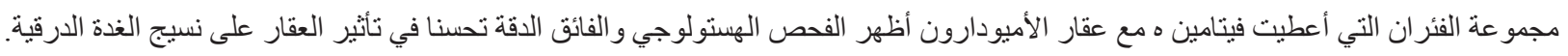
ومن هذا البحث يمكن إستتناج أن لعقار الأميودارون تأثيرات ضارة على الغدة الدرقية وهذا التأثير يقل بدرجة ملحوظة مع إعطاء فيتامين ه. 